\title{
RESEARCH PAPER \\ Clonal propagation of the avocado: effects of the rooting step on graft union formation and development
}

\author{
Carmen Estay, Ricardo Cautín, Alexander Neaman, and Mónica Castro \\ Escuela de Agronomía, Pontificia Universidad Católica de Valparaíso. Casilla 4-D, Quillota, Chile.
}

\begin{abstract}
C. Estay, R. Cautín, A. Neaman, and M. Castro. 2016. Clonal propagation of the avocado: effects of the rooting step on graft union formation and development. Cien. Inv. Agr. 43(2):233-241. The etiolation and layering technique that is used on avocados has two critical steps, namely, the rooting of clonal rootstock and graft union formation between the commercial variety and clonal rootstock. This study analyzed the rooting step of the clonal rootstock regarding its influence on graft union formation and development. The optimum times for grafting the commercial variety onto clonal avocado rootstock were determined under two greenhouse conditions, heating and no heating. The results showed that under greenhouse conditions without heating, there was higher survival (\%) in plants that were grafted 60 days after the rooting steps in the clonal scion, and, in the experiments in a heated greenhouse, the highest survival rate (\%) was observed in plants that were grafted 15 days after the rooting treatments. For both assays, the lowest survival rate was observed for grafts performed 30 days after the wounding and auxin application process. In histological cross sections of rootstocks at the wounding zone and in auxin treatments, a large number of emerging adventitious roots were developed at 30 days.
\end{abstract}

Key words: Grafting, histological cross section, Persea americana Mill, rhizogenesis.

\section{Introduction}

In Chile, commercial avocado plants are mostly grafted onto rootstocks from seeds, producing a large degree of heterogeneity in the plants (Castro et al., 2008). In addition to a trend towards planting in areas with increasingly limited edaphic conditions, this heterogeneity in the vegetation can lead to production problems (Castro et al., 2003). Moreover, obtaining

Received December 4, 2015. Accepted June 30, 2016. Corresponding author: monica.castro@pucv.cl clonal avocado rootstocks is still costly relative to production from seed rootstocks. For the clonal rootstocks, the cost results from a long propagation process and a considerable percentage of plant loss. Within this process, the most critical stages are survival subsequent to the grafting of the commercial variety and the rooting stage of clonal rootstock (Darrouy et al., 2010).

The development of a compatible scion consists of the following three events: close contact between the cambial zones of the scion and the rootstock 
(Hartmann et al., 2011), the proliferation of the callus cells and vascular re-differentiation (FloresVindas, 1999). However, Pina and Errea (2005) stated that callus formation may only be a passive response to being cut.

Adventitious roots arise endogenously, i.e., they are formed within the stem tissue and grow outwards (Hartmann et al., 2011). In addition, the capacity of the stems of several different species to form roots is partly related to the type of tissue present and its distribution. Thus, for example, in plants from the Salix genus, the rooting ability is very high because these plants have pre-formed adventitious roots. Species with wide vascular spokes also form roots easily, for plants such as the grapevine (Flores-Vindas, 1999) or the fig, in which the trunk has a large amount of parenchyma, implying intense metabolic activity (Baldini, 1992). Similarly, species with discontinuities in the phloem fiber ring produce roots more easily (Baldini 1992; Hartmann et al., 2011). The root primordia can originate in any part of the stem. In the case of plants in the first stages of growth, roots may emerge from the epidermis, parenchyma, phloem, and, with secondary growth, from the cambium and the stem marrow (Flores-Vindas, 1999). Oster et al. (2009 and 2013) stated that stems composed of juvenile matter show higher rooting capacity. However, Amissah et al. (2008) reported that the potential to produce roots is more related to the facility with which each species produces incipient roots than to the restrictions on the subsequent emergence of the roots.

Clonal propagation uses the etiolation technique to encourage cuttings to produce roots in plants that are described as being difficult for rooting. This approach is performed by inducing stem rejuvenation (Maynard and Bassuk, 1996, Husen, 2008 and Husen and Pal, 2006). With this technique, the stems experience reduced lignification in the secondary xylem, increased auxin concentration and lower periderm thick- ness (Maynard and Bassuk, 1996), along with the disorganization of the sclerenchyma fibers, favoring the formation of adventitious roots (Baldini, 1992). Significant increases in rooting have been described in hybrids of Leucaena (Mimosaceae) after using etiolation (Shi and Brewbaker, 2006). Muñoz and Rogel (1997) found that etiolated avocado shoots showed a higher rooting capacity than shoots without the preconditioning treatment. Husen (2008) indicated increases in Tectona grandis L.F. rooting after etiolation and increased plant sugar contents. Maynard and Bassuk (1996) state that plants that have been subjected to etiolation show increased starch concentrations. Muñoz and Rogel (1997) indicate that different responses were found in different avocado genotypes in terms of the ease of producing adventitious roots. Bender and Whiley (2007) show that etiolation is a prerequisite for producing roots.

In histological and anatomical studies that were performed during the grafting process in grapevines, the continuity in the cambium was established after 21 days, in most cases, and the process was complete between days 28 and 35 (Cangi et al., 2000). Papadimitriu et al. (2008) state that during rose propagation, the consolidation of the scion/ rootstock join and the formation of adventitious roots occur in parallel, forming a complete plant in 3 weeks. In accordance with this finding, the occurrence of events that demand physiological energy, such as rhizogenesis and the consolidation of the scion-rootstock bond in species such as rose and grapevine, which produce roots easily, do not have a significant influence on the efficiency of the propagation process.

Based on the above findings, the present study posits that simultaneous rooting and grafting would not be advisable in avocado. The objective of this study is, therefore, to determine the influence of the rooting stage of clonal rootstock on the survival of the scion and its subsequent development, thus defining the optimum time for performing the grafting of a commercial 
variety under greenhouse conditions with and without heating.

\section{Materials and methods}

This study was conducted at the Escuela de Agronomía of the Pontificia Universidad Católica de Valparaíso (PUCV), which is located in the Province of Quillota (32 $50^{\prime} \mathrm{S}$; $71^{\circ} 13^{\prime} \mathrm{O}$, at a height of 120 masl), in the Region of Valparaiso, Chile.

Assay 1. Effects of the rooting step of an etiolated shoot of clonal rootstock Duke 7 on graft union formation and development under greenhouse conditions without heating

This assay was performed in a $72-\mathrm{m}^{2}(6 \times 12 \mathrm{~m})$ metal greenhouse without heating and with a $0.15 \mathrm{~mm}$-thick transparent polyethylene roof. A total of 75 plants with Duke 7 clonal rootstock were used; they had etiolated shoots measuring $25 \mathrm{~cm}$ in length and four $\mathrm{mm}$ in diameter at 10 $\mathrm{cm}$ from the neck of the plant. The plants were separated into three groups of 25 for treatments, with three different grafting periods. Before the emergence of the shoots, soft (not hard) lateral wounding was applied to all the stem perimeters along the bottom $10 \mathrm{~cm}$ of the plant, after which an auxin mixture of indolebutiric acid (1600 ppm) and naphthalene acetic acid (1600 ppm) (diluted with $20 \%$ ethanol) was applied to the surface to promote the emergence of roots in this area. An aluminum ring was then placed at the base of the etiolated shoot. The $\mathrm{C}$-shaped ring was $1 \mathrm{~cm}$ in width, and it loosely surrounded the perimeter of the shoot to produce a gradual narrowing of the shoot as the plant grew and thus broke the vascular connection between the rootstock and the nurse plant. Finally, the container was fully extended and filled with peat and coconut fiber at a $3: 1(\mathrm{v}: \mathrm{v})$ ratio for the rooting of the stem in the wounding zone. Using a simple cleft graft to the $5-\mathrm{cm}$ slot above the root zone, these plants were grafted to the scion material of the Hass variety.

The treatments were as follows:

Treatment 1: grafting with the Hass variety two days after wounding and auxin application to the etiolated shoot of the rootstock.

Treatment 2: grafting with the Hass variety 30 days after wounding and auxin application to the etiolated shoot of the rootstock.

Treatment 3: grafting with the Hass variety 60 days after wounding and auxin application to the etiolated shoot of the rootstock.

At day 70 after the grafting, the survival rate (\%) of the scions were evaluated for each treatment, and the length and base diameters of the shoots were measured along the graft. The experiment employed a fully randomized design with three treatments and 25 repetitions for each one. A variance analysis was applied to the data along with the separation of means using Tukey's multiple comparison test $(\mathrm{P} \leq 0.05)$.

For the purposes of the histological study, one plant from each of the treatments was selected on the grafting day. A section of the stem measuring $2 \mathrm{~cm}$ in length was then extracted from the rooting zone of this plant. These pieces were fixed with formaldehyde, glacial acetic acid and alcohol (FAA) and transported to the Histology Laboratory of the PUCV to take histological cross-sections both lengthwise and transversally for subsequent anatomical analysis.

To obtain the stem cross sections of the treatments, the samples were dehydrated in an alcohol battery with increasing percentages from 70 to $100 \%$ (v:v) in three xylol baths and finally submerged in paraffin (Merck Histosec, Darmstadt, Germany) at its melting point $\left(60^{\circ} \mathrm{C}\right)$. Stem cross sections were taken at thicknesses of 12 to $14 \mu \mathrm{m}$ using a Minot rotary microtome manufactured by $\mathrm{R}$. 
Joung AG, of Heidelberg, Germany. Finally, the stem cross sections were stained with $1 \%$ safranin and $0.2 \%$ fast green. They were then observed at 10x and 40x magnification under an Olympus ${ }^{\circledR}$ CX31 optical microscope.

Assay 2. Effects of the rooting step for etiolated shoots of clonal rootstock Duke 7 on graft union formation and development under heated greenhouse conditions

This assay spanned the period from the planting of the seeds to the establishment of the Duke 7 grafts with the commercial variety. It was conducted in a heated greenhouse over a range of temperatures from 17 to $35^{\circ} \mathrm{C}$. A total of 100 Duke 7 rootstocks were used, and their $25 \mathrm{~cm}$ long-by-4 mm-diameter etiolated shoots measured $10 \mathrm{~cm}$ from the neck of the plant. They were separated into groups of 25 plants, each of which was subjected to the same procedure as in assay 1 as follows: wounding, application of hormones, installation of an aluminum ring, and grafting.

The treatments were as follows:

Treatment 1: grafting with the Hass variety two days after wounding and auxin application to the etiolated shoot of the rootstock.

Treatment 2: grafting with the Hass variety 15 days after wounding and auxin application to the etiolated shoot of the rootstock.

Treatment 3: grafting with the Hass variety 30 days after wounding and auxin application to the etiolated shoot of the rootstock.

Treatment 4: grafting with the Hass variety 60 days after wounding and auxin application to the etiolated shoot of the rootstock.

In this assay, the same variables as those in assay 1 were analyzed, and an identical experimental design was used.

\section{Results and discussion}

Assay 1. Effects of the rooting step for etiolated shoots of clonal rootstock Duke 7 on graft union formation and development under greenhouse conditions without heating

The highest survival rate (\%) of 'Hass' on Duke 7 clonal rootstock was for the grafting that was performed 60 days after wounding and auxin application, followed by the grafts performed after two days (Table 1). The roots of the clonal rootstock are very well developed after 60 days, and they can be felt outside the bag. The rootstocks also showed very good aerial development over this period, and they better supported the demands of the subsequent grafting process. Baldini (1992) indicates that the graft rootstock bonding mechanism is influenced by nutritive and hormonal factors, which would, therefore, be supported by the more developed plants. After 60 days, the stem of the rootstock is also more developed, thus facilitating the grafting task and increasing the probability of coincidence in the cambial zones of the graft and the rootstock. This finding is consistent with the indications of Hartmann et al. (2011) and Bender and Whiley (2007). It is important to note that this assay was conducted in a cold greenhouse, implying a lower energy cost in comparison with the assays conducted in the heated greenhouse.

Table 1. Graft union formation (\%) of avocado cv 'Hass' on 'Duke 7' clonal rootstock on three grafting dates following wounding and auxin application to the etiolated shoot in a greenhouse without heating.

\begin{tabular}{lc}
\hline Graft date & Graft union formation (\%) \\
\hline Two days & $58 \mathrm{~b}$ \\
30 days & $34 \mathrm{c}$ \\
60 days & $63 \mathrm{a}$ \\
\hline
\end{tabular}

Different letters indicate significant differences (Tukey's test, $\mathrm{P} \leq 0.05)$.

Grafting that is performed at 60 days after the wounding and auxin application treatment can be very useful; for example, when no material is available for grafting during the typical period in Chile. The plants that were grafted two days 
after wounding and auxin application also showed a high survival rate, which may be partly related to the application of auxins to the rooting zone.

In the histological cross sections of the rooting zone that were taken two days after wounding and auxin application (Figure 1A), root initials were not observed. This may be because the plants that were grafted two days after being wounded were etiolated and were recently subjected to mechanical wounding and grafting almost at the same time, and, therefore, part of their reserves are used to seal the wounded lines and to begin forming adventitious roots. Baldini (1992) and Hartmann et al. (2011) stated that when the stem is wounded, the surrounding cells die off and release substances during drying, after which a periderm is formed on the cells beneath the scar, which takes time. Therefore, no competition arises during the stage between rooting and graft survival. Analyzing the rooting zone 30 days after wounding and the auxin application showed a high degree of adventitious root emergence on the Duke 7 clonal rootstock, which would lead to competition with the survival of the 'Hass' scion. The avocado is described as a species that is difficult to root, which leads to more competition between the two physiological processes (Papadimitriu, et al., 2008; Cangi et al., 2000).

Upon observing the histological cross sections of the etiolated 'Duke 7' shoots two days after wounding and auxin application (Figure 1), and upon grafting with the commercial variety, development was observed in the cortical parenchyma and abundant phloem parenchyma surrounding well-defined and isolated groups of phloem fibers. Loufty (2009) describes the formation of irregular groups of sclereids in the phloem and cortex in juvenile avocado stems and the formation of an increasingly continuous ring of sclerenchyma, hindering the rooting process. The wounding of the etiolated stem of the Duke 7 clonal rootstock should help to break the sclerenchyma ring that may have formed, despite the etiolation of the plant. The parenchyma, however, is a de-differentiable tissue that facilitates the emergence of adventitious roots in this area (Flores-Vindas, 1999; Baldini, 1992). The secondary phloem and the cambium may also organize incipient roots, though the parenchyma spokes are more often responsible for this process (Baldini, 1992). The same author also states that endogenous phytoregulators with rhizogenesis effects are accumulated in etiolated stems; the cortical tissues are thicker and richer in parenchyma, and the fibers that accompany the phloem are less dense. Figure 1B shows that the spokes are formed by a single thread of parenchyma cells in the transverse cross-section, which is characteristic of the Lauraceae family, of which avocado is a member; it belongs to the primitive Magnoliidae subclass.

In the histological cross sections taken 30 days after the wounding and auxin application process, the emergence of abundant adventitious roots can be observed (Figure 1C and 1D). This finding is consistent with the lower survival percentage of these grafts. The low survival rate (\%) of these plants may be caused by competition arising from the emergence of adventitious roots with the generation of tissue to bond the rootstock and the scion. Baldini (1992) states that the rooting, in this, case can be satisfactory, even when there are no pre-formed roots. However, it is necessary for roots to form as quickly as possible to avoid physiological processes that are competitive with rhizogenesis.

For the grafts that were performed 60 days after the wounding and application of auxin, the survival rate of these grafts was the highest. This rate may be related to the lower competition between rooting and survival because the peak adventitious root formation occurred at day 30. The 'Duke 7' plants grafted after 60 days attained good root development, which, according to Hartmann et al. (2011), may be because the presence of leaves on the stem stimulated the initiation of root growth. These researchers also indicate that the carbohydrates that were transported from the leaves were able to contribute to the formation of 

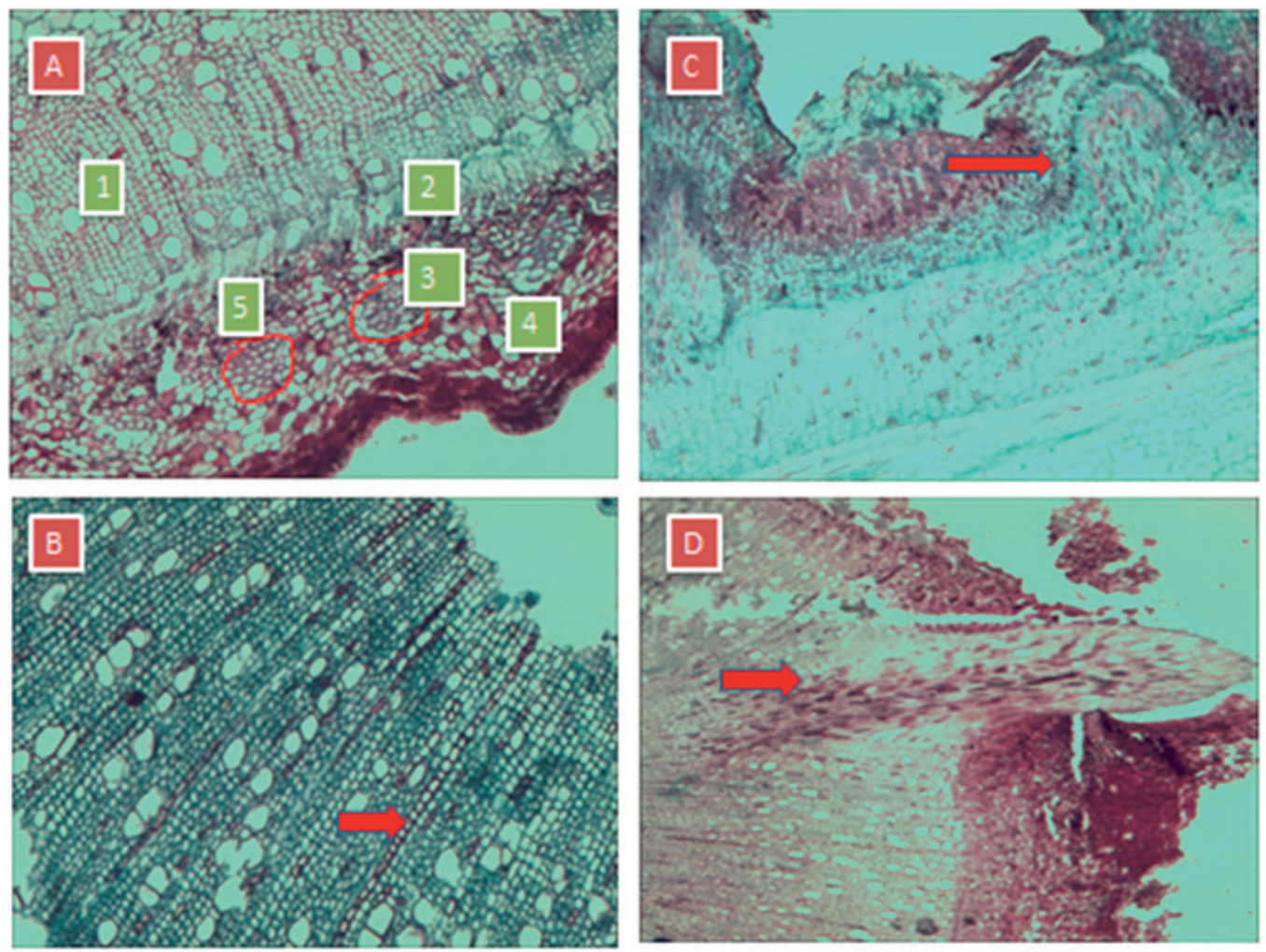

Figure 1. A) Transverse section of etiolated stem from 'Duke 7' avocado in the rooting zone taken two days after the wounding and application of auxin, where 1, xylem; 2, cambial zone; 3, phloem fibers; 4, parenchyma; and 5, phloem B) Transverse sections of secondary xylem from avocado stems, where showing C) longitudinal sections showing root initials and D) transverse sections of the rooting zone of etiolated 'Duke 7' stem 30 days after the wounding and application of auxin to plans showing root initials (10x).

roots because leaves and shoots are major auxin producers.

Whiley (1990) indicated that the leaves grew quickly, reaching full size after 30 days, and the shoots reached their maximum $\mathrm{CO}_{2}$ assimilation capacity 60 days after bud break. According to Baldini (1992), another factor that regulates the formation of adventitious roots is the nutritional status of the organs used in propagation, particularly their carbohydrate content.

Hartmann et al. (2011) indicate that by grafting onto already-established rootstocks, the rootstock produces most of the callus, and these callus cells penetrate the necrotic layer that has formed on both the graft and the rootstock to make the bond and create the mechanical basis to allow for the passage of water and nutrients between the rootstock and the graft.

The variables of graft union formation (Table 1), shoot length and graft diameter (Table 2) did not differ significantly between treatments. According to these results, once the graft has successfully taken hold, the shoots achieve equal development in terms of length and diameter, regardless of the period of time between auxin application and grafting. 
Table 2. 'Hass' growth in length and diameter after 70 days, according to different grafting dates next to the wounding and auxin application to the 'Duke 7' etiolated shoot in a non-heated greenhouse.

\begin{tabular}{lcc}
\hline Graft date & Shoot length $(\mathrm{mm})$ & Shoot diameter $(\mathrm{mm})$ \\
\hline Two days & $12.2 \mathrm{a}$ & $3.8 \mathrm{a}$ \\
30 days & $16.6 \mathrm{a}$ & $3.6 \mathrm{a}$ \\
60 days & $11.9 \mathrm{a}$ & $3.6 \mathrm{a}$ \\
\hline
\end{tabular}

Different letters indicate significant differences (Tukey's test, $\mathrm{P} \leq 0.05$ ).

Assay 2. Effects of the rooting step for etiolated shoots of clonal rootstock Duke 7 on graft union formation and development under heated greenhouse conditions

In this assay, the highest survival rate (\%) was found among the plants that were grafted 15 days after the wounding and auxin application process, followed by those that were grafted two days after this process and those grafted 60 days after. The lowest survival rate was found for plants that were grafted 30 days after the root induction process (Table 3). Carefully removing the substrate and observing the rooting zone of the rootstock at day 30 after the lesion process shows a large number of adventitious roots of up to $2 \mathrm{~cm}$ in length.

Table 3. Graft union formation (\%) of avocado cv 'Hass' on 'Duke 7' clonal rootstock over four grafting dates after wounding and auxin application to the etiolated shoot in a heated greenhouse.

\begin{tabular}{lc}
\hline Graft date & Graft union formation (\%) \\
\hline Two days & $76 \mathrm{~b}$ \\
15 days & $92 \mathrm{a}$ \\
30 days & $60 \mathrm{c}$ \\
60 days & $76 \mathrm{~b}$ \\
\hline
\end{tabular}

Different letters indicate significant differences (Tukey's test, $\mathrm{P} \leq 0.05$ ).

Gil (2009) states that two to three weeks (14 to 21 days) after grafting to a rootstock that is in active growth (in spring or summer), the differentiation of the new cambium begins in the callus in contact with both parts of the graft. In the case of avocado, and according to the results obtained here, it would not be advisable to graft avocados 30 days after the wounding and auxin application process because it would lead to competition for nutrients, unlike what has been observed in roses (Papadimitriu et al., 2008). Sallaku et al. (2012) stated that in cucumbers (Cucumis sativum) that were grafted to commercial rootstocks (Cucurbita maxima x C. moschata), a positive effect on the development of the graft can be achieved by prior root pruning, i.e., by decreasing the competition arising between the rooting and the graft/rootstock bond.

No significant differences were observed in the lengths of cv. Hass shoots (Table 4). However, for the shoot diameters, differences were found between treatments 1 and 4, 1 and 3 and 2 and 4, with the largest shoot diameter observed for plants that were grafted two days after the wounding and auxin application process. The smallest shoot diameter was obtained for the plants grafted 30 days after wounding and auxin application, which coincides with the lower graft union formation of these grafts.

Table 4. 'Hass' graft development growth as evaluated in terms of length and diameter at 70 days after grafting according to different grafting dates next to wounding and auxin application to the 'Duke 7' etiolated shoot in a heated greenhouse.

\begin{tabular}{lcc}
\hline Graft date & Shoot length $(\mathrm{mm})$ & Shoot diameter $(\mathrm{mm})$ \\
\hline Two days & $14.3 \mathrm{a}$ & $3.69 \mathrm{a}$ \\
15 days & $15.4 \mathrm{a}$ & $3.68 \mathrm{ab}$ \\
30 days & $14.8 \mathrm{a}$ & $3.01 \mathrm{bc}$ \\
60 days & $14.7 \mathrm{a}$ & $3.21 \mathrm{c}$ \\
\hline
\end{tabular}

Different letters indicate significant differences (Tukey's test, $\mathrm{P} \leq 0.05$ ).

The results obtained in this study show that the rooting stage is a strong antagonist to the bond between the graft and the rootstock during the clonal propagation of avocado.

In the greenhouse without heat, the highest graft union formation rate (\%) was achieved for plants that were grafted 60 days after the wounding and auxin application process. However, in the heated greenhouse, the bonding process between the graft and the clonal rootstock occurs sooner, obtaining the best response after just 15 days. 
Under greenhouse conditions with and without heating, the lowest graft union formation rate (\%) and lowest degree of graft development were found for plants grafted 30 days after the wounding and auxin application process. In this case, this result coincides with the observation of a higher degree of root development on the rootstock.

\section{Resumen}

C. Estay, R. Cautín, A. Neaman y M. Castro. 2016. Propagación clonal en palto: efecto de la fase de enraizamiento sobre el prendimiento y desarrollo del injerto. Cien. Inv. Agr. 43(2):233-241. La técnica de etiolación y acodo utilizada en palto presenta dos etapas críticas: el enraizamiento del portainjerto clonal y el prendimiento del injerto entre la variedad comercial y el portainjerto clonal. En este estudio se evaluó la influencia de la fase de enraizamiento del portainjerto clonal sobre el prendimiento y desarrollo del injerto. Definiendo los momentos óptimos para realizar la injertación de la variedad comercial sobre el portainjerto clonal de palto, en dos condiciones de invernadero con y sin calefacción. Los resultados mostraron para las condiciones de invernadero sin calefacción, mayor prendimiento (\%) en plantas injertadas a los 60 días después de los pasos de enraizamiento en la púa clonal, mientras que en el ensayo realizado en invernadero calefaccionado el mayor prendimiento (\%) se observó en plantas injertadas a los 15 días después de realizados los tratamientos de enraizamiento. Para ambos ensayos, el menor prendimiento (\%) se observó en plantas injertadas a los 30 días después de realizado el lesionado y la aplicación de auxinas. En cortes histológicos realizados al portainjerto, en la zona del lesionado y aplicación de la mezcla auxínica, a los 30 días, se observó gran cantidad de raíces adventicias emergiendo.

Palabras clave: Cortes histológicos, injertación, Persea americana Mill, rizogénesis.

\section{References}

Amissah, J.N., D.J. Paolillo, and N. Bassuk. 2008. Adventitious root formation in stem cuttings of Quercus bicolor and Quercus macrocarpa and its relationship to stem anatomy. Journal of American Society of Horticultural Science 133:479-486.

Baldini, E. 1992. Arboricultura General. Ediciones Mundi-Prensa. Madrid, España. 379 pp.

Bender, G.S., and A.W. Whiley. 2007. Propagación. p. 177-197. In: Whiley, A.W. and B. Schaffer and B.N. Wolstenholme (eds.). El palto, botánica, producción y usos. CABI Publishing-EUV, Valparaíso, Chile.

Cangi, R., F. Balta, and A. Dogan. 2000. Anatomical and histological investigations on the effects of stratification substrates on final take and quality of grafted vines. Turkish Journal of Agriculture and Forestry 24: 393-398.
Castro, M., C. Fassio, and N. Darrouy. 2008. Portainjertos de palto en Chile. Horticultura Internacional 62:42- 46.

Castro, M., C. Fassio, N. Darrouy, and A. BenYa'acov. 2003. Determinación de rangos de variabilidad en los niveles de producción del cultivar Hass sobre portainjertos de semilla de raza Mexicana en Chile. In: Actas V Congreso Mundial del palto. Granada- Málaga, España. Octubre 19-24. p. $155-160$.

Darrouy, N., M. Castro, R. Cautín, L. Kort, and R. Bozzolo. 2010. Efecto de la posición de la yema y de la poda en plantas de aguacate destinadas a la clonación. Revista Fitotecnia Mexicana 33: 249-256.

Flores-Vindas, E. 1999. La Planta: Estructura y Función. Editorial Tecnológica de Costa Rica. Costa Rica. 367 pp. 
Gil, G. 2009. Fruticultura. El Potencial Productivo. Ediciones Universidad Católica de Chile. Santiago de Chile. 398 pp.

Hartmann, H.T., D.E. Kester J.F.T. Davies, and R.L. Geneve. 2011. Hartmann and Kester's Plant Propagation: Principles and Practices. New Jersey: Prentice-Hall. United States of America 928 pp.

Husen, A. 2008. Stock-plant etiolation causes drifts in total soluble sugars and anthraquinones, and promotes adventitious root formation in teak (Tectona grandis L.f.) coppice shoots. Plant Growth Regulation 54: 13-21.

Husen, A., and M. Pal. 2006. Effect of serial bud grafting and etiolation on rejuvenation and rooting cuttings of mature trees of Tectona grandis Linn. South African Journal of Plant and Soil. 23(4): 316-317.

Loufty, M. 2009. Wood anatomy and its implications on the taxonomy of Apollonias Nees (Lauraceae). Feddes Repertorium 120(1-2): 75-90.

Maynard, B., and N. Bassuk. 1996. Effects of stock plant etiolation, shading, banding, and shoot development on histology and cutting propagation of Carpinus betulus L. fastigiata. Journal of American Society of Horticultural Science 121: 853-860.

Muñoz, R.B., and I. Rogel. 1997. Ensayos sobre propagación clonal de portainjerto de aguacate. In: Memoria 1997. Fundación Salvador Sánchez
Colín, CICTAMEX, S.C. (ed). CICTAMEX, S.C. Coatepec Harinas, México. p: 107-112.

Oster, G., M. Stefancic, and F. Stampar. 2009. Juvenile stockplant material enhances root development through higher endogenous auxin level. Acta Physiologiae Plantarum 31: 899-903.

Oster, G., V. Schmitzer, and F. Stampar. 2013. Carbohydrate involvement in rooting success of leafy cuttings depending on physiological age of stock plants of Prunus subhirtella 'Autumnalis'. Acta Horticulturae 990: 423-428.

Papadimitriou, M., A. Antonidaki-Giatromanolaki, M. Dragasaki, and I. Vlahos 2008. Bench T-budding technique as a means to propagate greenhouse roses under mist. Propagation of Ornamental Plants 8: 99-101.

Pina, A., and P. Errea. 2005. A review of new advances in mechanism of graft compatibility-incompatibility. Scientia Horticulturae 106:1-11.

Sallaku, G., A. Balliu, Z. Teqja, I. Babaj, and P. Rama. 2012. Root pruning effects on growth and stand establishment rate of cucumber grafted seedlings. Acta Horticulturae 960: 211-217.

Shi, X., and J. Brewbaker. 2006. Vegetative propagation of Leucaena hybrids by cuttings. Agroforestry Systems 66: 77-83.

Whiley, A. 1990. $\mathrm{CO}_{2}$ assimilation of developing fruiting shoots of cv Hass avocado (Persea americana Mill). South African Avocado Growers' Association Yearbook 13:28-30. 
